\title{
AGOS: the creation of a collective Armenian identity
}

\begin{abstract}
AGOS, a weekly bilingual Armenian newspaper, is a good example of a minority newspaper that politicises Armenian identity. This research-based study analyses whether the newspaper has managed to create a collective identity for the Armenian community in contrast to mainstream society and a state policy which ignores minorities and their collective identity. The study evaluates how, and in what context, the newspaper has constructed a collective identity for Turkey's Armenians. The study argues that the newspaper primarily aims to inculcate readers towards the democratisation of Turkey, while defending the identity of the community and voicing the problems which stem from state policies. The study is based on surveys conducted with one hundred Armenians, structured interviews with thirty participants and semi-structured interviews with Hrant Dink, the founder of the newspaper, and Mayda Saris, its art director.
\end{abstract}

Keywords: minority ethnic media, collective identity, Turkey's Armenians, Turkish politics, minority rights in Turkey.

\section{Introduction}

The Ottoman Empire collapsed under the imperial powers of the era with the aid of the Empire's minorities. When the Turkish nation state arose from the ashes of the Ottoman Empire, the minorities began to be perceived as a potential threat to the new Republic. The failure of the Armenians to establish their own state during the Ottoman period resulted in the events of 1915, the forced 'Armenian Resettlement', since Armenians were classified by the Turkish elite as 'others', together with their counterparts such as the Greek minority. Minorities in Turkey enjoyed almost all the same rights as the majority, but the state perceived them as a security issue and ignored them and their collective identity in both the public and political spheres. AGOS, a weekly bilingual Armenian newspaper in Turkey, established in 1996, aims to help Armenians survive in their communities.

$A G O S$ is a minority newspaper that politicises the Armenian identity and fosters the visibility of the community in the public sphere. The newspaper has become a political voice for Turkey's Armenians. When the newspaper's founder and editor, Hrant Dink, was murdered on 19 January 2006 by Ogun Samas, a young Turkish ultranationalist, on the premise that Dink had insulted the Turkish identity with his writings, the newspaper became even more popular in Turkey and renowned in Armenian circles throughout the world. Dink, through $A G O S$, was the first minority person in the country to criticise the Turkish state politically in the public realm. Through Dink, and $A G O S$, Turkish mainstream society has rediscovered the existence of Turkey's Armenian community. 
After its establishment in 1996, AGOS has mainly focused on politicising Turkey's Armenian identity and making this identity publicly visible. It has re-established a framework for Armenian identity and such a politicisation has found supporters among Turkey's Armenian community. The newspaper is not only read by Armenians but also by other minorities, mainly Greeks and Jews, and by mainstream society, particularly on the left. The newspaper aims to create a collective identity among Armenians which runs counter to the state's perception of minorities, ignoring them in both the public and political spheres. The existence of $A G O S$ is perceived as a struggle to make Turkey's Armenians visible.

In this context, the aim of this article is to analyse whether the newspaper creates a collective identity within the Armenian community in contrast to mainstream society and a state policy which hides minorities and their collective identity. The article aims to evaluate how, and in what context, this weekly bilingual Armenian newspaper has been able to construct a collective identity for Turkey's Armenians. It comprises two main sections:

- the first section evaluates the two profound processes of collective identity - 'boundary creation' and 'consciousness' - and the role of the media in generating these processes

- the second section sheds light on the political and historical situation that gave rise to the establishment of $A G O S$. This section also analyses whether $A G O S$ provides for boundary creation and consciousness within the Armenian community.

To achieve the aims of the study, the main themes were determined from topics, news, advertisements and articles and confirmed through the help of semi-structured interviews with Hrant Dink on 4 November 2005 and with Mayda Saris on 30 December 2005. Subsequently, the results of a survey of one hundred people and from structured interviews with a sub-sample of thirty were compared and contrasted with the emergent themes so as to generate an understanding of the extent to which $A G O S$ plays a role in generating an Armenian identity within Turkey.

The survey participants, using the 'snowball system', come from regular Armenian $A G O S$ readers, with male and female participants almost equally divided. The survey, conducted between February and May 2007, included 126 questions categorised into four sections:

1. political stance

2. cultural stance

3. questions on perceptions of identity

4. perceptions and thoughts on $A G O S$.

For the structured interviews, thirty participants (fifteen males and fifteen females) were selected from the one hundred survey participants.

Tense conditions within the country made going into the Armenian community to conduct the research something of a challenge. An Armenian friend of the researcher helped overcome this problem by conducting the survey and the interviews within the community. The researcher had no direct contact with any of the participants, except for Dink and Saris and one participant within the Armenian community who wished to remain anonymous: the Armenian friend made handwritten notes on the answers of the participants. 


\section{Collective identity and minority media: 'boundary creation' and 'consciousness'}

Collective identity, such as ethnic identity and national identity, refers to the reconstitution of the individual self around a new and valued identity. For Taylor and Whittier, collective identity is:

The common definition of a group acquired by its members' common interests, experiences and solidarity. ${ }^{1}$

Melucci also defines the concept as:

The process collectively creating the cognitive and emotional definitions of what actors feel when they are challenged with an environment or the 'other', which eventually leads to a collective action. ${ }^{2}$

Collective identity is not a natural phenomenon. It is an imagined feeling that can be produced, strengthened and changed by collective action. ${ }^{3}$ Both social and ethnic groups need a social and political construct which forces the ethnic, or social, group to create a collective identity to sustain the survival of its community. Such an identity must be continuously supported through rituals and actions. Melucci considers collective identity as a process in which cognitive definitions regarding outcomes, means and action are utilised. ${ }^{4}$ Thus, collective identity is fostered by the interaction of the members of the group through interaction and communication with, and the influence of, one another. Models of leadership, communication instruments and communicative channels strengthen the collective boundaries of the group. ${ }^{5}$

Gerson and Peis identify two important dimensions of collective identity: 'boundaries' and 'consciousness', which serve as instruments in understanding the relationship between media and the collective identity. ${ }^{6}$ Boundaries indicate political, social, psychological and physical structures that indicate differences between challenging and dominant groups. ${ }^{7}$ Establishing boundaries is essential in separating a sub-

1 Verta Taylor and Nancy Whittier (1992) 'Collective Identity in Social Movement Communities' in Adam D. Morris and Carol McClurg Mueller (eds.) Frontiers in Social Movement Theory New Haven and London: Yale University Press: p. 105.

2 Alberto Melucci (1988) 'Getting Involved: Identity and Mobilisation in Social Movements' in Bert Klandermans et al. (eds.) From Structure to Action: Comparing Movement Participation Across Cultures: International Social Movement Research Vol. 1 Greenwich: JAI Press, pp. $329-48$.

3 Heidi Wedel (2001) Siyaset ve Cinsiyet (Politics and Sexuality) Istanbul: Metis Yayinlari, p. 32.

4 Alberto Melucci (1995) 'The Process of Collective Identity' in Hank Johnston and Bert Klandermans (eds.) Social Movements and Culture London: UCL Press, p. 44.

5 Ibid.

6 Cited in Taylor and Whittier, op. cit. pp. 104-129.

7 David Morley and Kevin Robins (1995) Spaces of Identity: Global Media, Electronic Landscapes and Cultural Boundaries London and New York: Routledge, p. 46. 
ordinate group from 'others' to create a feeling of 'us' and 'them'. However, a social movement cannot entirely separate itself from the environment in which interaction with the 'other' occurs, as it is crucial for that social movement to be aware of itself. There must be a minimal degree of correspondence between the movement and players in society and in the state. ${ }^{8}$

Boundary creation is essential for social movements like Armenians in Turkey, who allege they are an aggrieved group due to their minority status in Turkey. In this respect, the group perception of aggravation leads to a withdrawal of their values and support from mainstream society and enables them to create their own values, discourses and economic and political structures. Thus, the group creates its own public sphere in relation to others. ${ }^{9}$

Apart from the political, social, cultural and economic boundaries, the socio-psychological side of a collective identity, the formation of a collective memory, is essential, particularly for ethnic groups. Collective memory generation automatically separates a group from 'others' by the creation of an indigenous history for the group. This memory construction can be grounded in heroic events, but it can also be based on a group's 'narrative of victimisation'. ${ }^{10}$ The first generation of a group can pass trauma on to subsequent generations. For Volkan, an event causing trauma binds individual psychology to group psychology. Members in a group form a common mindset as the outcome of all the images which stem from all the emotions, perceptions, fantasies and interpretations shared by the group. ${ }^{11}$

The second process in the construction of collective identity is consciousness. It is difficult to separate this process entirely from boundary creation. Consciousness is the interpretative framework of a social group emerging from struggle, creating common interests between group members as part of the process of fighting against the dominant order. The concept signifies an ongoing process in which groups:

Re-evaluate their subjective experiences and their opportunities, and their shared interests. ${ }^{12}$

This process both determines the structure of an ethnic group and provides strategies and expectations in the determination of collective action in political and public spheres. The members inside a group socialise according to the norms and values of the group during this process. The process not only entails the teaching of group values, norms and structures, but also reinforces the members to act in terms of the group's common strategy. ${ }^{13}$

8 Melucci, op. cit.

9 Cited in Taylor and Whittier, op. cit. pp. 105, 111-113.

10 Vamik Volkan (1999) Kanbağı Etnik Gururdan Etnik Teröre (Blood Ties: From Ethnic Pride to Ethnic Terrorism) İstanbul: Bağlam Yayınları, pp. 54-57.

11 Ibid.

12 Taylor and Whittier, op. cit. p. 114.

13 Francesca Polletta and James M. Jasper (2001) 'Collective Identity and Social Movements Annual Review of Sociology 27, p. 288. 
The minority ethnic media serve, in this process, as a catalyst in the fostering of boundary creation and consciousness formation amongst minority ethnic groups that do not want to be assimilated into mainstream society. Minority ethnic media provide 'free opportunity space' or an 'ethnic minority public sphere' and generate discourses amongst the minority ethnic group that subsequently strengthen the group's collective identity. News, articles and advertisements constituting the content of a newspaper stimulate the creation of symbols and rituals for the group. ${ }^{14}$ The media have the power to define and interpret news, generate public opinion and fabricate common references. Thus, the minority media strengthen collective identity by generating a collective consciousness. To understand the relationship between collective identity and minority ethnic media, it is crucial to evaluate the structure of that minority ethnic media and the collective identity thus engendered. ${ }^{15}$

\section{Minority media and collective identity}

Minority ethnic media play a strong role in giving a voice to minorities, thus enabling minorities to realise their ethnic identities. Hence, minority ethnic media not only present the identity of the minority ethnic group and make minorities visible in civil society, but also create a collective consciousness for ethnic identity which, in Benedict Anderson's words, is known as the 'imaginary community'. ${ }^{16}$ The other function of minority ethnic media is to make mainstream society aware of the existence of the minority ethnic group and the problems faced by its members. Some minority ethnic media function towards the assimilation of a minority ethnic group, but others - such as the mass media - can play a vital role in preventing the assimilation of a minority. The focus of this article is the evaluation of the latter.

Ethnicity is a social construct phenomenon in which minority ethnic media stimulate the construction of borders and the strengthening of consciousness. Minority ethnic media, particularly newspapers, produce symbols, rituals and discourses and organise these in reference to their survival strategies. Such a reconstruction of borders and reinforcement of the consciousness of a minority ethnic group can also be called social representation. Social representation is a means to generate the collective identity of a group and the topics addressed in a newspaper, to a certain extent, present the social representation of a specific group. ${ }^{17}$

Such social representation is, however, insufficient for minority ethnic groups. The content and style of the presentation, such as news, advertisements or pictures, reinforce the ideological elements and patterns of ethnic identity. This leads to the reconstruction of borders for the minority ethnic group and bolster members' con-

14 Stephan Harold Riggins (1992) 'The Promise and Limits of Ethnic Minority Media' in Stephan Harold Riggins (ed.) Ethnic Minority Media: An International Perspective London: Sage Publications, pp. 282-284.

15 Ibid.

16 Ibid; Benedict Anderson (1991) Imagined Communities: Reflections on the Origin and Rise of Nationalism London and New York: Verso, pp. 5-7.

17 Anthony S. Rausch (2003) Collective Identity Creation and Local Revitalization http:// www.japanesestudies.org.uk/articles/Rausch.html [accessed 4 May 2005]. 
sciousness, thus preventing them from assimilating into mainstream society. ${ }^{18}$ Stephan Riggins's four features of minority ethnic media - the use of minority language; the construction of a minority agenda; announcements of community events; and the symbolic significance of minority ethnic media - play a role in preventing the assimilation of an ethnic group by reinforcing consciousness and boundary creation. These features provide profound materials for evaluating the subject of this article. ${ }^{19}$

\section{The use of minority language}

Minority ethnic media promote an ethnic minority language, thereby contributing to the survival of the language and reminding young people of their ethnic language. ${ }^{20}$

\section{The construction of a minority agenda}

Mainstream media generally set their own agenda which usually gives little attention to minority ethic people and their needs. Minorities feel they are ignored by such media, arguing that they focus on the wrong events or on topics of little interest. However, minority media give minorities a chance to set their own agenda based on the patterns of their priorities, thereby strengthening the identity of minority ethnic groups and determining their life strategies. ${ }^{21}$

\section{Announcement of community events}

Community events are important in terms of reinforcing solidarity for the members of an ethnic group and underpinning unification within the group. The announcement of social activities leads to participation by members of ethnic groups, thereby paving the way for strengthening ethnic identity. Minority ethnic media amplify interaction among community members spread over wide areas who have little or no information about one another. ${ }^{22}$

\section{Symbolic significance of minority ethnic media}

Minority ethnic media play a significant role in preventing assimilation. They set the agenda in reference to particular minority ethnic demands and create a public minority ethnic sphere, paving the way for members of the minority ethnic group to be proud of themselves. This feeling results in resistance to assimilation attempts. ${ }^{23}$

The four features of minority ethnic media strengthen the consciousness and boundary creation of minorities. Bias in photographs, topics and headlines, as well as the narration of the content, as determined by a minority ethnic newspaper, provides the minority with a feeling of being agents for change rather than objects suffering from change. Minority ethnic media generate a counter-ideology that prevents assimilation into mainstream society.

18 Riggins, op. cit. pp. 282-284.

19 Ibid, pp. 282-284.

20 Ibid, p. 283.

21 Ibid.

22 Ibid.

23 Ibid, p. 284. 


\section{AGOS and the formation of Armenian identity}

\section{Socio-historical conditions prior to the establishment of AGOS}

With some 60000 people, Armenians are the most populous minority in Turkey, settling predominantly in Istanbul. A majority of the population is Catholic, but Protestants and members of the Orthodox faith are also found within the community. Turkey's Armenians have their own primary and high schools, but are free to attend national schools. The community has 38 churches and some twenty schools, as well as twenty associations engaging religious, cultural and social issues in Istanbul. ${ }^{24}$ It also has two sports clubs: Sisli and Taksim; two newspapers: Marmara and Jamanak, as well as $A G O S$; and one hospital. ${ }^{25}$

The Armenian community has been closed to outsiders since its experiences in the Ottoman period, especially in $1915,{ }^{26}$ and in the period of the Turkish Republic arising from the state's mistrust of minorities. ${ }^{27}$ Armenians have predominantly settled in the Kadikoy, Sisli, Yesilkoy, Bakirkoy, Besiktas, Yenikoy and Moda districts in Istanbul, where Armenian associations exist. Generally, these associations are financially and morally dependent on the Armenian patriarchy, and churches and schools are usually conducted together. These function as the branches of Turkey's Armenian patriarchy, representing the community in Turkey and abroad. The Armenian patriarchy plays a role as the administrative and moral institution of the Armenian community, which forms the collective identity of Armenians. The patriarchy does not want to politicise the Armenian identity in Turkey, but it does protest against biased news and discourses on Armenians which are proclaimed and publicised in the mainstream media.

24 Armenians live in 23 cities in Turkey, but they mostly live in Istanbul as they can embrace their culture more easily there; the associations and Armenian schools exist in Istanbul.

25 Istanbul Armenians Bolsohays: www.Bolsohays.com [accessed 4 April 2007]; Yahya Kocoglu (2001) Azinlik Gencleri Anlatiyor (Young People From Different Minorities Narrate) Istanbul: Metis, pp. 122-123.

26 The trouble between Armenians and the Ottoman Empire started under the strong influence of a newborn nationalist ideology amongst Armenians from 1870. Nationalist feelings transformed into dissident movements among minorities in the Empire generally, including Armenians. However, Armenians were the last minority to rebel against the state, perceived as they were by the state as the most loyal Christian millet in the country. Armenian organisations rebelled against the state until 1915, when the state halted their actions by military force. At the beginning of World War I, the tragedy of the Armenian forced resettlement, referred to as the 1915 event, or forced resettlement, in official Turkish ideology and otherwise as genocide, decimated the Armenian population in the early $20^{\text {th }}$ century.

27 The National Independence War of 1919-1923 heralded the destruction of the Ottoman Empire and the establishment of a Turkish Republic grounded on strict nation-state principles. This mindset reflected that the minorities were perceived as the sinister enemy of the country during the Republican period although the Lozan Agreement, signed by the Turkish Republic and the European powers in 1923, adjusted the country's citizenship policy and minority rights regime. 
Armenians in Turkey were negatively affected by the 1941 Wealth $\operatorname{Tax}^{28}$ and the events of 6-7 September 1955;29 consequently, many Armenians migrated from Turkey to the west. Another factor that affected Turkey's Armenians was the Armenian Secret Army for the Liberation of Armenia (ASALA), an Armenian terrorist organisation carrying out terrorist actions against Turkish diplomats in Europe. According to Patriarch Mesrop II, ASALA and its terror actions, linked to Turkey's Armenians by some state officials and in the Turkish public sphere, led to another wave of migration in the Armenian community. ${ }^{30}$

In the late 1980s and 1990s, the transformation of Turkey from state-led capitalism to free market economy resulted in a liberalisation in both politics and civil society, and it became a driving force for the emergence of some social movements surrounding the demand for identity recognition. ${ }^{31}$ Similar circumstances led to the emergence of the Kurdistan Workers Party (PKK) terror organisation, which demanded separation from Turkey, and the augmentation of an armed struggle by the PKK with the Turkish security forces. This situation led the state to prioritise security and to perceive democracy and democratic demands in society as a security threat. ${ }^{32}$ Within this process, the state generated a discourse on Kurds living in Turkey in contrast to the PKK's discourse on Kurds, arguing that the terror organisation wanted to monopolise the representation of Kurds in Turkey. Armenians, not Kurds, were highlighted as an enemy in the state's discourse, which held that 'Armenians constituted the

28 The Republican elite wanted to nationalise the country via its agenda of constructing a Turkish nation-state in 1923. The situation, however, did not correspond with the nationalist agenda of the Republican elite and led it to nationalise the economy. The most important step in this direction was the wealth tax imposed by the state in November 1942, mostly to curb the wealth of Christian minorities. According to the law, Christian minorities would pay the state ten times more than Muslims. Those who were not able to pay the tax were sentenced to heavy labour in work camps. The result was that many minorities sold their possessions and left the country. Ayhan Aktar (2006) Varlık Vergisi ve Türkleştirme Politikalarl (Wealth Tax and Turkification Policies), Istanbul: Iletişim, pp. 17-71.

29 On 6 September 1955, the Turkish state radio channel announced that Ataturk's house in Selonika had been bombed. This event led to outrage in the Turkish public sphere and it led to violent acts being perpetrated by the protesters on the possessions of minorities in Istanbul, including the looting and damaging of their houses and shops. The state did not take a direct role in this outrage, but police forces failed to take serious measures against the protestors. According to Dilek Güven, the results were the continuation of the ethnic and demographic homogenisation process of the new Turkish Republic: Dilek Güven (2005) Cumhuriyet Azinlik Politikalari Baglaminda 6-7 Eylul Olaylari (The Events of 6-7 September in Relation to the Republic's Minority Rights Regime), Istanbul: Tarih Vakfi Yayinlari, pp. 173-177.

30 Cited in Sedat Laçiner and Kamer Kasim (2004) 'Istanbul Ermeni Patriği II. Mesrop İle Söyleyişi' ('Conversation With The Istanbul Armenian Patriarch Mesrop II') The Journal of Turkish Weekly 28 October 2004 http://www.turkishweekly.net/turkce/makale.phb?id=13.

31 Rifat N. Bali et al. (2002) 'Yahudi, Ermeni ve Rum Toplumlarında Milliyetçilik' in Tanil Bora (ed.) Milliyetçilik (Nationalism) İstanbul: İletişim Yayınları, p. 922.

32 Rasim Ozgur Donmez Europeanization of Turkey Exeter: University of Exeter, unpublished $\mathrm{PhD}$ dissertation, pp. 167, 339. 
majority of PKK militants, not Kurds' and 'Armenians comprised the PKK'. 33 The state's perception had another negative impact on Turkey's Armenian community. Armenian Patriarch Mesrop II explains it thus:

First, the ASALA's terror actions were attributed to Turkey's Armenians and then more than one governor, whose rationale cannot be understood, identified Turkey's Armenians with the PKK and targeted them in the public sphere. Foremost, the state official channel TRT and the other media's incredible broadcasts and publications bolstered the vision identifying the PKK with Armenians, evoking anger and hatred in large sectors of the Turkish society against Armenians. In this period, Turkey's Armenians implicitly, or explicitly, faced reaction within the state sector. ${ }^{34}$

An important reason existed for the state setting up this discourse. Most Armenians were not within the PKK, but the state deliberately used this discourse to avoid eroding the homogeneous image of Turkish identity, with Islam the strongest element and Kurds perceived as a part of this due to their Muslim identity.

Based on the 1923 Lozan Agreement, the Republican elite had implemented a policy of the homogenisation of different Muslim communities under the concept of Turkish identity. Non-Muslim communities, including Armenians, enjoyed full citizenship rights; however, there was a negative impact concerning ethno-cultural and religious diversity in that the imagined unity of the Muslim millet remained integral against the 'other' position of non-Muslims. The Turkish state defined a line between 'Turkish nationality' and 'Turkish citizenship'. The minorities were perceived in the second category and excluded from the privileged position of Turkish nationality. Consequently, Turkish authorities as well as the public began to perceive nonMuslims as 'foreign' and 'suspect' within the Turkish-Muslim nation, meaning that minorities found themselves in a vulnerable position. ${ }^{35}$

In this context, the discourse identifying Armenians with the PKK prevented the alienation of Kurds and Turks from each other in the perception of the state's elite.

The other development in the 1990s was the wave of liberalisation in the mainstream Turkish media. For Rifat Bali and others, this wave led to the rediscovery of 'others' in Turkish society, paving the way for Armenians to appear in public and giving Turkey's Armenians a chance to voice their problems in the public sphere and to claim their rights. ${ }^{36}$ This gave the Armenian patriarchy the chance to proclaim to the media that the PKK-Armenian collaboration propaganda was inaccurate.

Meanwhile, the patriarchy decided to establish an Armenian newspaper printed in Turkish; ${ }^{37}$ subsequently, AGOS, a bilingual Armenian newspaper, was founded by the current editor and by Hrant Dink and his friends Luiz Bakar, Harutyan Sesetyan

33 Alper Urus (2003) Türkiye'deki Azınlık Gazeteleri Eskisehir: Eskişehir Anadolu Üniversitesi, unpublished Masters thesis, p. 48.

34 Cited in Laciner and Kasim, op. cit.

35 Ahmet İçduygu and B. Ali Soner (2005) 'Turkish Minority Rights Regime: Between Difference and Equality’ Middle Eastern Studies 42(3), pp. 453-455.

36 Rifat N. Bali et al., op. cit. p. 922.

37 Urus, op. cit. p. 48. 
and Anne Turay. The twelve-page newspaper includes ten pages in Turkish and two pages in Armenian.

The main mission of the newspaper is to communicate with Turkish citizens of Armenian descent who cannot speak Armenian, particularly those immigrating to Istanbul from the eastern part of the country, and to share the problems of the community through the newspaper. Moreover, it aims to improve the negative image of Armenians in the public sphere and to play a role in defending the rights of Armenians both in Turkey and abroad. ${ }^{38}$ In this respect, the newspaper addresses the 1915 events and the problems facing Turkey's Armenians stemming from Turkey's minority rights regime and the state's anti-democratic practices, as well as the diaspora of Turkey's Armenian patriarchy and unjust criticism of Turkey and Turkey's Armenians. Many Armenians in Turkey, ideologically and politically, have gathered around $A G O S$, which has become a political player within Turkey's Armenian community, in contrast to the apolitical attitude of the patriarchy and its financial and political monopoly within the community. The group of people gathered around AGOS is generally comprised of middle-class Armenians keen on politicising their Armenian identity.

The rationale for establishing the newspaper is also evident in the meaning of the newspaper's name, in both Turkish and Armenian, which refers to the furrows on the land created by a plough where water drains off, indicating Armenian-Turkish cooperation. The newspaper has a circulation of 5000 and covers events, news and problems relating to Armenians. ${ }^{39}$

\section{Boundary creation}

Boundary creation in collective identity helps to distinguish a community from others, by separating the community or the collective identity from the others, and to form the community's own identity by setting social, cultural and economic boundaries, particularly for ethnic groups. In this respect, the minority ethnic newspaper addresses two functions as regards boundary creation: the generation of an 'own sphere' within the mainstream's public space; and the identification of the 'other'.

\section{Toward the new Armenian public sphere}

The most important rationale for $A G O S$ is to communicate to Armenians in Turkey who cannot speak Armenian. The newspaper is trying to form a new Armenian public sphere or, in Pierre Bourdieu's thoughts, an Armenian 'Habitus' ${ }^{40}$ The newspaper contains news and articles that address the community's problems, as well as

Ibid.

Interview: Mayda Saris.

'It can be understood as the set of acquired patterns of thought and behaviour. These patterns are inculcated by a group or society through internalization of culture or objective social structures. This is possible through the experience of individual or group'. Guney Cegin and Kemal Can Pierre Bourdieu: Pratiklerin Mantigi, Habitus ve Alan Teorisi: http:// www.bisav.org.tr/yayinlar/bulten_makale_detay.cfm?makaleId=3088\&yayin_sayi=25 [accessed 27 December 2007]. 
events about Armenians and about Turkey's Armenian community that could possibly affect their lives. The new public sphere for Armenians thus generated within the national public sphere strengthens the collective identity of the Armenian community and prevents its members from being assimilated into mainstream society.

AGOS has a minority ethnic agenda and provides information both in Turkish and in Armenian. The objective of the pages in Turkish is to communicate with Turkish citizens of Armenian descent who cannot speak Armenian and is aimed at forming the boundaries of the community. Including two pages in Armenian symbolically reminds Armenian-speaking members of their identity. The newspaper contains news and columns on Turkey's Armenian community and documents Armenian traditions. The first page comprises events that could possibly affect the Armenian community, or which have already done so, and also covers the political actions and agendas of the community in Turkey as evidenced by the following headlines:

- 'Moderate optimism is dominant: eyes are diverted to the meeting between the leaders of Azerbaijan and Armenia held in August in Kazan'41

- 'The Armenian Church celebrates the birth of Jesus'42

- 'We should not create tolerance myths'. ${ }^{43}$

Page five covers news and columns about art and is focused predominantly on Armenian literature, artists and films about Armenians, although other art news from around the world is also included:

- 'Karin Karakaşl1: amateur but a professional writer'44

- 'Professional advertisement photographer Ani Celik Arevyan has been taking photographs since he was 19 years old'. ${ }^{45}$

This page aims to inculcate Armenian art and culture in the Armenian community. Mayda Saris stresses that she gives great importance to using the columns of the newspaper for news about Armenians, to acquainting Armenians with Armenian art and to presenting Armenian culture.

Page three includes announcements about community and sporting events in the Armenian public sphere. A most important feature of minority media is their ability to acquaint members of the minority community with one another; to reinforce communication within the community and thereby strengthen the collective identity. For example, Armenians' success in sports, science, business and academia is included on this page:

$41 \operatorname{AGOS}$ (2005c) ‘Ölçülü Bir İyimserlik Hakim' ('Moderate optimism exists') 5 August, p. 1.

42 AGOS (2001a) 'Ermeni Kilisesi İsa'nın Doğuşunu Kutladı' ('The Armenian Church celebrates the birth of Jesus') 5 January, p. 1.

43 AGOS (1996a) 'Hoşgörü Mitosu Yaratmayalim' ('We should not create tolerance myths') 14 June, pp. 1, 7. This refers to a conference on 7 June 1996 at which representatives of the Jewish, Armenian and Syriac community spoke.

44 She is a Turkish Armenian author.

45 AGOS (1996c) 'Profesyonel Reklam Fotoğrafçısı Ani Çelik Arevyan 19 Yaşından Beri Fotoğraf Çekiyor' ('Professional advertisement photographer Ani Celik Arevyan has been taking photographs since he was 19 years old') 5 June, p. 8. 
- 'Daron Acemoglu from Istanbul living in the USA is one of the best economists in the world'. ${ }^{46}$

The sports section contains news about Armenians, including Turkey's Armenian high school basketball league, as well as Armenian athletes around the world, such as:

- 'Andre Agassi, one step forward and one step back'. 47

Birth and death announcements are included on page three and also bolster the collective identity. A 23-year-old boy pointed this out during the study:

My grandfather told us he became aware of his relatives whom he had not seen for a long time through $A G O S$.

The survey which was conducted as part of the current study asked participants about the learning effects of $A G O S$ in the creation of boundaries. In response to the question 'What kind of publications, other than AGOS, do you follow?', $27 \%$ indicated all publications of interest, $25 \%$ pointed to publications announced in $A G O S$ and $12.5 \%$ answered publications on the problems of minorities. Clearly, AGOS bolsters communication within the community. Moreover, most participants mentioned that they first access the birth and death announcements, information about the community and advertisements in $A G O S$. A 49-year-old housewife explained:

We Armenians can inform each other through AGOS.

In short, the content of $A G O S$ aims to obstruct the assimilation of the minority by strengthening communication within the community and creating a boundary for collective identity.

\section{The symbolic significance of minority ethnic media in minority ethnic newspapers}

Minority ethnic media such as $A G O S$ create a minority ethnic public space, paving the way for the minority ethnic group to enhance pride in its community without being assimilated into mainstream society. The creation of this minority public space is a most important outcome of collective identity formation.

The focus in $A G O S$ on integrating without assimilating into mainstream society enhances Armenians' visibility in Turkey's public sphere. Saris confirms that the

46 AGOS (2001c) 'Bu Başarıyı Tanıyoruz: İstanbullu Daron Acemoğlu ABD'de Dünyanın En İyi Ekonomistlerinden Birisi' ('We know this success: Daron Acemoglu from Istanbul living in the USA is one of the best economists in the world') 3 August, p. 3.

47 AGOS (2001d) 'Andre Agassi: Bir İleri Bir Geri' ('Andre Agassi: one step forward and one step back') 3 August, p. 3 . 
newspaper was initially established to articulate Armenian voices in mainstream society. Hrant Dink underscores this:

This is a newspaper for defending our problems, rights and identities against the state and the society. Our aim is to open the community to mainstream society, be part of the democratisation of Turkey and communicate with Armenians who are not able to speak Armenian.

To understand this situation better, the survey asked participants why they read AGOS: $43 \%$ of participants stressed that the newspaper reflects their problems concerning their Armenian identity, while another $26.7 \%$ stated that $A G O S$ voiced their identity in the public sphere. One 23-year-old female stated simply:

Because I am Armenian,

while a 24-year-old man stressed that:

It is a high-quality newspaper and represents my ideas.

Undoubtedly, AGOS plays an important role as a voice for Armenians, proclaiming the problems facing this minority ethnic group within the public sphere. Consequently, this mission of the newspaper hinders the assimilation of Turkish Armenians into mainstream society.

\section{The creation of the 'other'}

A minority ethnic group can establish its boundaries by distinguishing itself from 'others'. In this context, minority ethnic media play the role of a stimulus mechanism in showing and generating the 'other'. ${ }^{48}$ AGOS depicts its borders by characterising both Turkish nationalists and Turkish security policies as 'others' and by making criticisms of the Turkish minority rights regime.

The Turkish state perceives minorities from the perspective of the security situation due to the historical establishment of traumatic psycho-political dynamics and its own ideological structure. Minorities in the country enjoy full citizenship rights but they have implicitly been obstructed from working in the state's security sectors. Moreover, minority cultural environments have been constrained by the state, subjecting minorities to the national homogenisation of the Turkish state through the Republican understanding of 'responsible' Turkish citizenship. This perspective of the state has ignored minorities in the public space but, within the state sector, it has also segregated minorities from mainstream society by creating a 'step citizen' versus 'real citizen' cleavage. Dink emphasises that the definition of minorities is avoided in any primary or high school book, yet it occurs in the national security curriculum which

48 See Young Khee Kim and Sun Han (2003) 'The Gwanju People's Uprising and The Construction of Collective Identity: A Study on Fighters' Bulletin' New Political Science 25(2), pp. 207-223. 
underscores the state's perception of minorities. Dink's assertions are reflected in the topics and headlines of the newspaper:

- 'Although the Turkish Armenian community goes to Ankara once or twice a year to solve their problems stemming from the state itself, these problems are always ignored'49

- 'Anna Turay, a director of $A G O S$, talked on behalf of Turkey's Armenian community, noting that the solutions of minority problems are embedded in the defence of citizenship rights'. ${ }^{50}$

In the current survey, $53.4 \%$ of the participants mentioned they did not have confidence in certain state sectors, including its security sectors, while $28.4 \%$ declared that they did trust the state; $15.9 \%$ were non-committal. Some $71.6 \%$ said that they did not rely on political parties and $20 \%$ did not have confidence in them. A total of $74 \%$ put their trust in civil society organisations while $15.9 \%$ declared negative opinions about political parties.

Turkish nationalists are another factor influencing Turkey's Armenians. The perspective of Turkish nationalists on citizenship is patterned on cultural features and ethnic heterogeneity, which affects Turkey's Armenians. The reactions of some Armenians to such a disruption by Turkish nationalists have intensified the negative perception of Turkish nationalists. During the interviews, one young girl who lived on Kartal, a street in Istanbul, mentioned that her family's houses:

Were stoned due to their Armenian identity.

Saris notes the complexity of the situation:

We love Turks and we cannot blame anyone for the events that happened in 1915. Kazim Karabekir's daughter is my good friend. ${ }^{51}$ We do have a problem with nationalists and their discourses. An ex-minister used the expression, 'Armenian Sperm' when she was swearing at someone.

Dink further explains:

I do not have any problems with anyone, but I do have problems with marginal nationalist sectors of society that avoid me and show me as a target. They do it in their newspapers. They are not keen on an Armenian becoming visible in the public sphere by explaining their identity vigorously, but they should get used to it.

49 Hrant Dink (2001) 'Sapparigce: Oki Azınlıksın' ('Sapparigce: Okay! You are a minority’) AGOS 26 January, p. 12.

50 AGOS (1996a) op. cit.

51 Kazim Karabekir was the commander of the Eastern Front in 1915 and commanded the troops applying the policy of 'forced resettlement'. 
Such ideas are also reflected in the content of the newspaper:

- 'The live performance in vandalism exhibition'52

- 'Here is Turkey! Racism is free!'.53

Indeed, $95.5 \%$ of the participants stated that the most serious problem facing Turkey is nationalism. However, $64.7 \%$ perceived Turkish nationalists as the 'others', while $22.4 \%$ saw both Turkish and Kurdish nationalists as the 'others'.

\section{Consciousness}

Consciousness simply refers to an interpretative framework of a social group emerging from a struggle that creates common interests among the members of the group during the struggle against the dominant order. AGOS tries to enhance the consciousness of its readers by focusing in two directions: ${ }^{54}$ the democratisation of Turkey; and, related to this, the engagement of identity politics in constitutional citizenship.

The newspaper primarily aims to orient its readers toward the democratisation of the country while defending the identity of the members of the community and articulating the problems which stem from state policies. To this end, AGOS first reminds its readers of their past so as to generate a collective memory. It reminds them of Armenians' unofficial history; in particular, the events of 1915. The 1915 'forced resettlement' remains a strong parameter in Turkey's Armenian identity, as it is for all Armenians in the world, and this plays a profound role in the newspaper. Other traumatic events for the Armenian community, including the 1942 Wealth Tax and the events of 7-9 September 1955 in Turkey, also make their way into the pages of $A G O S$. The newspaper stresses Armenians' migration history which, to a great extent, vanished after the resettlement of Armenians in 1915, as well as biographies of Armenians living in the Ottoman Empire and modern Turkey, and descriptions of places and important events. Dink explains that $A G O S$ aims to incorporate the events of 1915 into mainstream society. Saris further notes that $A G O S$ is in charge of protecting Armenians' heritage, as evidenced in these stories:

- 'A memory of lost Istanbul'55

- 'Mr. Asadur the coffee seller'56

52 AGOS (2005e) 'Vandalizm Sergisinde Canli Performans' ('The live performance in vandalism exhibition') 9 September, p. 1. '...The Grey Wolves coming to an exhibition on 6-7 September threw eggs at the pictures and pulled them out of place, while shouting slogans such as "Turkey is for Turks and will remain for Turks."...'.

53 AGOS (2005) 'Burası Türkiye! Irkçılık Serbest!' ('This is Turkey! Racism is free!') 28 April, p. 1.

54 Taylor and Whittier, op. cit. p. 114.

$55 \operatorname{AGOS~(1997a)~'Kayip~Istanbul~Anisina'~('A~Memory~of~Lost~Istanbul')~} 21$ February, p. 12. '...Once upon a time, Pera was a place where Greeks, Armenians, French, Italians, Russians and Turks lived together, but now...'.

56 AGOS (1997b) 'Kahve Saticisi Asadur Bey' ('The Coffee Seller Mr. Asadur') 28 February, p. 6. 'Mr. Asadur the coffee seller took over the coffee shop located in Arnavutkoy from his father in 1959. Arnavutkoy was, at the time, a multicultural place consisting of Armenians, Greeks, French, Jews...'. 
- 'On method'57

- 'Two histories of my childhood'. 58

When survey participants were asked to identify the philosophy of $A G O S, 64 \%$ stressed that the role of the newspaper is to remind of historical events, such as 1915, and of the Armenian community while promoting these within mainstream society. During the interviews, all the participants emphasised that $A G O S$ reminded them of their history. In this context, $A G O S$ presents an alternative history, differing from the official one, which it has inculcated in Armenian readers.

Dink states that the state still perceives Armenians in the context of security issues. During the interview, Saris highlighted this notion, pointing out that the state had sued Dink for an article indicating that Mustafa Kemal Ataturk's adopted daughter, Sabiha Gokce, was Armenian. Such undemocratic practices of the state against Armenians are evident in the newspaper:

- 'The unbearable lightness of being a minority'. ${ }^{59}$

The readers mostly share the same perspective as the publishers. During the survey and the interviews, all the participants mentioned that the state, to some extent, treated Armenians unjustly. One 24-year-old female stressed:

We are not treated justly and everyone talks negatively about us. Everyone in this country has the right to swear at us. Those talking about us positively are judged as nonsensical.

AGOS highlights Turkey's EU accession process as important, providing prominent space for news and articles about the EU. During the interviews with both Saris and Dink, they stressed that the EU accession process was important for the democratisation of the country and the improvement of the conditions of minorities. In this context, the newspaper anticipates an improvement in the conditions of minorities and minority associations; for example, concerning the right to buy land in Turkey. ${ }^{60}$ During the survey, the participants defined what the EU meant for them: $38.4 \%$ stres-

57 '... Forgetting the pains of millions of losses (Armenians) before and after World War I, represented by some sectors of the society as a virtue, signifies an anomaly...' The losses signify the pains of Armenian people stemming from 'forced resettlement' and the Ottoman repression of Armenian organisations in 1894, leaving hundreds of people dead.

58 Baskin Oran (2005) 'Çocukluğumdan İki Tarih' ('Two histories in my childhood') AGOS 29 September, p. 11. '... An event similar to the September 6-7 experience in the islands. Dozens of mobs raided my house. They broke windows and stoned the windows of the children's bedroom...'.

59 Rifat N. Bali (1996) 'Azınlık Olmanın Dayanılmaz Hafifliği' ('The unbearable lightness of being a minority') AGOS 21 June, p. 2. '... The words of Armenians, Jews and Greeks used in the daily discourse of the media indicating wickedness shows how minorities are depicted in the visual and written media...' AGOS (2005a) 'Komisyondan Uyarı' ('Warning from the Commission) 22 June, pp. 1-7. 
sed the democratisation of the country; while $32.6 \%$ said that it would enhance the country's prosperity. One 22-year-old man stated:

I do not care about the outcomes of the EU for myself, but I am concerned about the positive outcomes that will affect Turkey... I hope the Turkish economy will improve.

Another policy of $A G O S$, within the consciousness process, involves engaging with identity politics in the context of accessing constitutional democracy. After the 1980s, various political ideologies perceived the state as autocratic (ceberrut) and found civil society a place where they could realise their political agenda. The curtailment of classical left- and right-wing movements based on class antagonism allowed identity politics to appear. Dink, as the architect of the newspaper, was affiliated with new left politics and began to follow identity-based politics during this period. Dink explains:

We all supposed that everything would be all right after winning the class struggle. However, we saw within the class struggle that life was not just constituted of the class struggle. There are other struggles in life, like identities, which are phenomena that are incontrovertible. This was a phenomenon that was learned, experienced and practised in my life.

In this sense, $A G O S$ approaches identity on the basis of constitutional democracy, conceptualising citizenship on the grounds of critical responsibility to 'others' and securing identity/differences through the constitution. The newspaper criticises an understanding of Turkish citizenship which is based on the French understanding of citizenship patterned on territory and the homogenisation of differences within the citizenship concept. ${ }^{61}$ AGOS supports cohesiveness within Turkey and the Turkish state, yet promotes the recognition of Armenians and other minorities by the state through their identities. Saris underscores that $A G O S$ supports multiculturalism. Dink agrees, asserting that a civilised and contemporary understanding of citizenship necessitates the construction of the state by its citizens, not the construction of citizens by the state. However:

There has been no citizenship in this country; rather, there has been a master and servant relationship.

The newspaper holds that minorities and other identities should support the virtue of citizenship while simultaneously promoting a public space in which they can ex-

61 Ahmet İçduygu and Fuat Keyman (1998) 'Globalleşme, Anayasallık ve Türkiye'de Vatandaşlık Tartışması' ('Globalisation, Constitutionalism and Citizenship Debates in Turkey') Doğu Batı 2(5), pp. 143-154. 
press their identities without limitation by the state. The $A G O S$ website identifies this succinctly:

Turkey is beautiful with minorities included. ${ }^{62}$

During both the survey and the interviews, the participants stated they are not able freely to live their culture in the public space. Indeed, $76.7 \%$ defined the Turkish state as a community of citizens while $10.5 \%$ defined it as a state governing the territory where Turkey is located. Three in five participants $(60.5 \%)$ defined the motherland in which they lived as a political and public formation in which citizens live; the second most selected answer was land that is inseparable from its state. In this category, participants responded to another question: 'What does the Turkish nation mean to you?' In response, $58.1 \%$ stated that it was a community of citizens gathered via laws; $18.6 \%$ answered that it was a community in which people wanted to live under a uniform flag; and $14 \%$ considered that such questions had no concrete answers. In defining being Armenian, $52.3 \%$ of the participants stressed they are a people still suffering from the events of 1915 , while $19.8 \%$ indicated people who felt they were Armenian.

Within the consciousness process, $A G O S$ has tried to integrate Armenians into Turkish mainstream society while preventing them from being assimilated into it. To this end, it both voices the problems of Turkey's Armenians in both the political and the public sphere, and brings constitutional democracy to the forefront. This latter entails a cohesiveness with the Turkish nation as well as a criticism of the undemocratic practices of the state.

\section{Conclusion}

The Turkish Republic rose from the ashes of the Ottoman Empire destroyed by the imperial powers in co-operation with certain minorities aiming to separate themselves from the Empire. This situation resulted in a mistrust of minorities in the new Republic and many did not perceive them as a part of the nation. Furthermore, they were given the status of legal citizenship which put them in a vulnerable position. Indeed, the state almost made them invisible but minorities, including Armenians, were faced with prejudice from both state and society.

$A G O S$ is an example of a minority newspaper that has politicised the minority identity in Turkey. It seeks to create a collective Armenian identity against the policies of the state and the perspective of society towards Armenians, while focusing effort on preventing Armenians from being assimilated into mainstream society. Based on the results of interviews and the survey conducted for this study, AGOS has been able to create boundaries and a consciousness for Turkey's Armenians. The newspaper has built boundaries by constructing political-, cultural- and arts-based news, and announcing community events, while aiming to communicate with Armenians who cannot speak Armenian by printing the majority of the text in Turkish. To 
prevent Armenians who can speak Armenian from being assimilated into mainstream society, the newspaper provides two pages in Armenian.

In the consciousness process, both the newspaper and the participants in the survey are critical of the state's anti-democratic practices against minorities, but they do support a constitutional democracy patterned on securing different identities through the constitution. In this respect, all the participants perceive Turkish citizenship as a virtue, but they do want to be able freely to express their identity in the public sphere. Neither participants nor the newspaper want Armenian identity to be perceived as shameful; rather, they perceive it as a boon that enriches Turkey's culture.

In summary, $A G O S$ has a strong effect on its readers, inculcating the philosophy and parameters of the Armenian identity. A philosophy of promoting integration but not assimilation into mainstream society is proposed to its readers. $A G O S$ is a good example of how peaceful identity politics should be depicted in the public and political spheres. 